\title{
Preface and introduction
}

International maritime law traditionally has fallen to be studied in discrete blocks public law or private law, primarily. Much of the current legal scholarship in the field slots rather too neatly into these pre-conceived, artificially drawn domains. On either side of the divide is often a misunderstanding about the other. Private law thinking, especially that from the west, is largely concerned with the role of private law in preserving commercial relationships, whilst public law thinking has often concerned itself with the public good. In reality, of course, the shipping world operates without such artificially drawn boundaries. The private and the public are always inextricably connected. Lawyers and legal scholars favour working within a narrowly defined domain, understandably. I recall a conversation with a shipmaster once. His vessel was receiving bunker fuel at Qingdao supplied by the charterer. He was very concerned about whether the bunkers supplied were not "off-spec" - any damage caused to the ship as a result of off-spec bunkers would not be covered by insurance but would also lead to prosecutions if the ship, as a result of the inappropriate bunker, were to collide or ground causing environmental damage. To him, the "law" was the law - no thought about private or public law. Of course, not all classification is bad - and it can be useful to have a set of narrowly defined values, for example when querying specific aspects of the law. What is perhaps notable in this Research Handbook is the explicit recognition of the private and the public interest in the analyses.

The maritime sector could perhaps claim to be the first to be subject to internationally agreed common rules for both public and private. Sea transport conventions regulate the making of carriage contracts, whilst International Maritime Organization (IMO) instruments regulate the conduct of shipping business and operations. Moreover, there is clear and explicit veneration of the "contract" in both sets of norms. International rules largely leave matters of remedies, both substantive and procedural, to national law. An integrated study of international maritime law must therefore have regard to national law dealing with the issues of process, jurisdiction, judicial remedies and private remedies (such as arbitration). As regards the matter of private remedies, the maritime sector is fiercely protective of autonomy and regulatory intervention and thus often favours alternative dispute resolution. However, private remedies are not always entirely "private" given that in shipping there are networks of stakeholders involved in any so-called shipping arrangement. These are the central themes for this Research Handbook.

To this end, this Research Handbook in International Maritime Law is organised into four parts. 


\section{xii Research handbook on maritime law and regulation}

\section{PART I}

Part I focuses on the shape and direction of travel for transport convention law. There are two key themes here - one on the question how best to support international harmonisation through a more unified approach to the vexed matter of conflicting interpretations applied to internationally agreed rules. Legros, in this connection, raises a hitherto seldom considered question of whether there is a role for interpretive committees and discusses how a more uniform interpretive approach could be achieved, drawing from lessons elsewhere in public international law and transport law. Verheyen and Spanjaart are both concerned with the wider question of why transport law should necessarily be directed by the type or mode of transport in question. Verheyen shows the limitations of the current legal system in coping with the demands and needs of the industry. Industry seeks flexibility and transportation of goods in modern times must necessarily be guided by the need to respond to change quickly. A system of transport regulation which is based on the types of contract or modes of transport is inflexible. He advocates a rethinking of the whole idea of "mode of transportation" and providing a more modern definition of the notion. Spanjaart offers a similar perspective, arguing for the introduction of an international convention which borrows from existing norms but does not make a distinction between the different modes of transportation. Lamont-Black rounds off the discussion on law-making with a consideration of the position of freight forwarders. Shipping cannot operate with the involvement of freight forwarders who operate successfully because of their know-how of local markets. However, despite this "local" knowledge, they often adopt practices which are comparable across the world and have commercial interests similar to their counterparts in other markets. As such, despite their local orientation, they are exposed to similar risks. Lamont-Black is concerned with whether and to what extent the current top-down law-making could be reoriented towards a bottom-up approach by embedding industryled solutions via a Model Law for freight forwarding. Her work provides a perspective on the type of interaction required between law-making and (global) industry participation, which is relevant not only to the maritime and freight forwarding business in practical terms but also to transport regulation thinkers.

\section{PART II}

This part considers the role of public law regulation on shipping and examines the philosophical justification for the current systems, institutions and legislative processes for international maritime regulation. Chircop's work provides a theoretical framework to explain and facilitate understanding of international maritime regulation in the public law arena. The purpose of his work is to promote a better understanding of how the highly complex regulatory structures and processes operate as a system, against the mission of universality and uniformity in international maritime law and of the International Maritime Organization. Baughen chooses to focus on the workings of the European Union (EU) as a maritime regulatory institution, and using the example of marine environment damage points out how legal and regulatory developments by the supra-national organisation, however well intentioned, could threaten the integrity 
of the IMO system. Eftestøl-Wilhelmsson and Sankari consider the role of non-law influences to better compliance with maritime regulation, especially as regards greenhouse gas emissions. They question the effectiveness of the "choice architecture" in the current EU and international regimes and argue that nudging transport services users and stakeholders in choosing sustainable operations as the default should be incorporated in the regulatory approach and system.

\section{PART III}

This part takes on some key influences which shape the evolution of current commercial shipping law. The "golden thread" in this part is the understanding and characterisation of party autonomy in commercial shipping contracts. It is quite obvious that the matter of party autonomy takes on a textured complexion in international shipping, given the need for a high degree of commercial certainty. Contract law on the other hand is often concerned with the state directed allocation of risk. Although the contract between parties has significant influence in guiding the law's process of allocating risk, and hence liability, there are aspects of contract law which are ripe for a reassessment of their role vis-à-vis commercial shipping relationships. One notable area in the common law world, identified by Zhao, is the perpetuation of the classification of some terms as innominate terms. These are terms of which the consequences for breach could not be ascertained until only after the event of the breach. Zhao argues that this uncertainty is unfavourable to the commercial shipping environment where commercial certainty is needed. More specifically he expounds on the highly original proposition that English law (especially the law on penalties) does not seem adequately to accommodate the desire of the contracting parties to pre-agree the quantum of damages (or indemnities) for breaches of innominate terms. He is in favour of creating and respecting better party autonomy in this regard. Certainty also plays a central role in Hjalmarsson's work. Her ontological work identifies and proves the existence and use of hybrid forms of charterparties, and thus poses the wider question as to when and whether the shipping law system should properly recognise this category of charterparties. Without proper legal recognition or acknowledgement, this increasingly established shipping practice might be exposed to the whims of judicial interpretation of existing rules on the time charter, voyage charter or bareboat charter, but as we know, their rules are very much based on the particular and unique features of each of these charterparties and may not be easily transplanted to a hybrid charterparty. The net result might well be the loss of certainty for the industry and its stakeholders, and a loss of respect for party autonomy.

Following on from a discourse on party autonomy is Goldby's study of shipping liner contracts as contracts of adhesion. Whilst not questioning the need for party autonomy, she contends that where one party, viz. carrier, has the liberty to decide on whether or not a bill of lading should be issued, that does not constitute party autonomy. Judicial control of such types of power should take into account the imperatives of carriage conventions, notably for English law, the Hague Visby Rules. The interpretation of the protective provisions of the conventions should thus consider how modern contracting processes work in shipping so as better to ascertain properly the actual presence party 
autonomy. Lista's work, which looks to the bill of lading as a contract, is especially relevant to this discussion. He, in turn, questions the role of the bill of lading as a document of title and, hence, the principal determinant of the person lawfully entitled to the goods and all associated rights. He traces the historical roots of the bill of lading and challenges the current orthodoxy which assumes an understanding of the concept of "title". He points out for example that it is not always clear whether the concept of "title" in shipping law means that the lawful holder has ownership or simply an entitlement to the goods. Added to this highly conceptual question is the notion of "lawful holder". In order to cast light on the conundrum, he invites us to reconsider how the law, or legal ideas, about possession, property, ownership and contract rights developed in Roman law, given how important the Roman law roots were in helping to shape the development of the law on bills of lading.

The debate about party autonomy cannot avoid relying on general presumptions in contract law about the balance of power or bargaining positions. However, those general presumptions must be questioned, as regards the maritime network of interdependent contracts. It is for example not safe to assume that the supplier (namely the carrier) is always the stronger contracting party in a shipping contract. Macro-economic factors, such as market crises, fluctuation of commodity prices, geo-political changes and so on, all can happen quite suddenly and without warning, disrupting the balance of power. The shipping world has encountered in recent times severe economic turbulence; shipping insolvencies, once a rarity, have become much more commonplace. In these challenging economic times too, we have witnessed a gradual shift in a number of jurisdictions to encouraging better preservation of corporate assets by requiring by law the continuity of contracts. High value shipping contracts too are brought within the policy change. Chuah's work assesses the tension thus between party autonomy and insolvency legal and policy changes. His research urges caution when pushing for renegotiations and continuity of contracts, in this highly networked sector, and shows that there are significant tensions between rules of contract law, insolvency law and private international law which do not make matters clear, even if renegotiation is generally deemed to be a good thing.

\section{PART IV}

Part IV is primed to evaluate conceptual and intellectual challenges to resolution of shipping disputes, both in public and private law matters. Mukherjee examines the increasingly vexed question of jurisdiction over incidents occurring in specified maritime zones and the high seas. The question of conflict of jurisdictions or laws inevitably arises because these areas are subject to different legal domains. Mukherjee reasons that the traditional approach to resolving such disputes could benefit from a modified version of the substance-procedure dichotomy applied in admiralty law. His reliance on admiralty law concepts to address problems with civil jurisdiction over incidents in United Nations Convention on the Law of the Sea (UNCLOS) defined maritime zones and the high sea is especially original.

Returning to more conventional commercial disputes, Baatz posits her examination of civil jurisdiction in maritime disputes squarely on the premise of party autonomy or 
choice. She criticises the resource heavy approach in certain cases where party autonomy is derogated from because of so-called policy considerations. In other cases, courts are caught up in the interpretation of the technicalities of the rules - such as in marine insurance cases in the EU. Baatz also shows that the global landscape too is confused and inconsistent in its interpretation of party autonomy or jurisdiction agreements where third parties are concerned. The problem is particularly acute in maritime law because in any shipping related arrangement, there will be many parties involved whether in a network or a chain. Like Baatz, Todd's research question is concerned with third parties but the focus of his work is on arbitration agreements. His concern is the lack of coherence in the many interlocking regimes applicable to third parties in the maritime field. He surveys the legal landscape and identifies the different interlocking regimes and, drawing from relevant case law, shows how these regimes at best lead to confusion, and, at worst, lead to injustices. His evaluation also draws from common law gap-filling principles and contractual devices but concludes that without legislative intervention, despite the utility of these principles and devices, the lack of clarity will endure.

\section{CONCLUSION}

I am sure my contributors will agree with me that our hope is for the reader to draw inspiration from this work to develop and enhance their own research and interest in the subject. We believe we have proved that international maritime law has many layers from the commercial to the regulatory, from public to private, from substance to procedural, from the domestic to the international, and from legal to contractual. This work has also shown the maritime sector is no longer seen as maritime per se but must necessarily involve other modes of transport and other participants outside the conventional shipper and carrier. These different intersections make the subject intellectually challenging but the learning of the subject, I hope, has been made more accessible and edifying by my contributors.

Last, but not least, the contributors and I are grateful to the anonymous referees who have helped to make this Research Handbook a worthy new addition to Edward Elgar's now well established peer reviewed Research Handbook series.

Jason Chuah 
Jason Chuah - 9781786438799 